\title{
Clinical development of nintedanib for advanced non-small-cell lung cancer
}

\author{
This article was published in the following Dove Press journal: \\ Therapeutics and Clinical Risk Management \\ 16 November 2015 \\ Number of times this article has been viewed
}

\author{
Masayuki Takeda' \\ Isamu Okamoto² \\ Kazuhiko Nakagawa' \\ 'Department of Medical Oncology, \\ Kinki University Faculty of Medicine, \\ Osaka, ${ }^{2}$ Research Institute for \\ Diseases of the Chest, Graduate \\ School of Medical Sciences, Kyushu \\ University, Fukuoka, Japan
}

\begin{abstract}
Angiogenesis is an essential process in the development, growth, and metastasis of malignant tumors including lung cancer. Several angiogenesis inhibitors have been developed as potential therapies for non-small-cell lung cancer (NSCLC). Nintedanib is a smallmolecule tyrosine kinase inhibitor that targets receptors for vascular endothelial growth factor, platelet-derived growth factor, and fibroblast growth factor as well as RET (rearranged during transfection) and Flt3. When administered as monotherapy, nintedanib was well tolerated at doses up to $250 \mathrm{mg}$ or $200 \mathrm{mg}$ twice daily in European and Japanese patients, respectively, with liver toxicity featuring prominently among dose-limiting toxicities in both populations. A recent Phase III trial demonstrated that treatment with the combination of nintedanib and docetaxel resulted in a significant and clinically meaningful improvement in both progression-free survival and overall survival compared with docetaxel alone in predefined NSCLC patients with adenocarcinoma tumor histology. Although the incidence of elevated alanine aminotransferase or aspartate aminotransferase as well as of diarrhea was higher in patients treated with nintedanib plus docetaxel, most of these adverse events were manageable with supportive treatment or dose reduction. The results of completed and ongoing clinical trials of nintedanib monotherapy and combination therapy for the treatment of NSCLC are summarized in this study.
\end{abstract}

Keywords: nintedanib, non-small-cell lung cancer, dose-limiting toxicity, hepatotoxicity

\section{Introduction}

Lung cancer is the most common cause of cancer-related death worldwide, with non-small-cell lung cancer (NSCLC) being the major histological subtype of this malignancy. Both experimental and clinical studies have identified many molecules that contribute to the various biological behaviors of malignant tumors including NSCLC. Platinum-based chemotherapy regimens are the standard first-line treatment for individuals with advanced NSCLC who do not harbor identifiable driver oncogenes, such as mutant forms of the epidermal growth factor receptor gene or rearrangements of the anaplastic lymphoma kinase gene. However, the efficacy of such regimens has reached a plateau. ${ }^{1-5}$

Vascular endothelial growth factor (VEGF), a mitogen specific for endothelial cells, is the major regulator of angiogenesis in normal and malignant tissue. ${ }^{6}$ Increased expression of VEGF has been detected in NSCLC and is associated with poor prognosis. ${ }^{7}$ Preclinical studies showed that a mouse monoclonal antibody specific for VEGF inhibited the growth of human tumor xenografts when administered alone or together with chemotherapy. ${ }^{8,9}$ A humanized variant of this antibody, bevacizumab, has been extensively investigated in individuals with various types of solid tumor including NSCLC. Two large randomized Phase III studies (Eastern Cooperative Oncology Group 4599 and Avastin in Lung) found that bevacizumab provided a statistically
Correspondence: Isamu Okamoto

Chest, Graduate School of Medical

Sciences, Kyushu University,

3-I-I Maidashi, Higashi-ku,

Fukuoka 812-8582, Japan

Tel +8I 926425774

Fax +8I 926425775

Email okamotoi@kokyu.med.kyushu-u.

ac.jp
Therapeutics and Clinical Risk Management 20I5:I I I70I-I706

I70|

Dovepress

http://dx.doi.org// 0.2147/TCRM.S76646 (c) (i) (5) 2015 Takeda et al. This work is published by Dove Medical Press Limited, and licensed under Creative Commons Attribution - Non Commercial (unported, v3.0) BY NC License. The full terms of the License are available at http://creativecommons.org/licenses//by-nc/3.0/. Non-commercial uses of the work are permitted without any further permission from Dove Medical Press Limited, provided the work is properly attributed. Permissions beyond the scope of the License are administered by Dove Medical Press Limited. Information on
how to request permission may be found at: http://www.dovepress.com/permissions.php 
significant benefit when combined with chemotherapy compared with chemotherapy alone in patients with advanced nonsquamous NSCLC. ${ }^{10,11}$ On the basis of these findings, bevacizumab-plus-cytotoxic chemotherapy has become a standard treatment option for first-line therapy in patients with advanced nonsquamous NSCLC. Given the proof of concept that targeting of angiogenesis is an effective strategy for the treatment of NSCLC; several angiogenesis inhibitors are now in development for this condition.

Nintedanib (BIBF 1120) is a potent, oral, and broadly active small-molecule tyrosine kinase inhibitor with median inhibitory concentrations in the low nanomolar range: $13-34 \mathrm{nmol} / \mathrm{L}$ for $\mathrm{VEGF}$ receptors $1-3 ; 59 \mathrm{nmol} / \mathrm{L}$ and $65 \mathrm{nmol} / \mathrm{L}$ for platelet-derived growth factor receptors $\alpha$ and $\beta$, respectively; $37-108 \mathrm{nmol} / \mathrm{L}$ for fibroblast growth factor receptors $1-3$; and $26 \mathrm{nmol} / \mathrm{L}$ for Flt3. It is also active against members of the Src family of tyrosine kinases such as Lck, Lyn, and Src. ${ }^{12}$ In preclinical studies, nintedanib achieved sustained blockade of VEGF receptor 2 (VEGFR2) and induced marked inhibition of tumor growth in xenograft models of human renal cell, colorectal, ovarian, and prostate carcinoma as well as NSCLC. ${ }^{12}$ Strategies deployed to inhibit VEGF signaling in preclinical studies have thus been investigated in clinical trials of nintedanib for NSCLC.

\section{Nintedanib monotherapy Phase I trials}

A dose-escalation Phase I study was conducted in German patients with advanced solid tumors to determine the maximum tolerated dose (MTD) of nintedanib as well as to evaluate the safety of continuous once- or twice-daily treatment with the drug (Table 1). ${ }^{13}$ A total of 25 and 36 patients received nintedanib at a dose of $50-450 \mathrm{mg}$ once daily or
150-300 mg twice daily, respectively, in 4-week cycles each followed by a 1 -week washout. Dose-limiting toxicities (DLTs) were apparent in one of the eight patients treated with $200 \mathrm{mg}$ once daily (elevation of aspartate aminotransferase [AST] and $\gamma$-glutamyl transpeptidase $[\gamma-\mathrm{GT}])$, in one of the six patients treated with $250 \mathrm{mg}$ once daily (reduction in the number of $\mathrm{CD}^{+}$lymphocytes), and in two of the five patients treated with $300 \mathrm{mg}$ once daily (elevation of AST and $\gamma$-GT in one and of alanine aminotransferase [ALT] and AST in the other). DLTs also developed in one of the six patients treated with $200 \mathrm{mg}$ twice daily (reduction in the number of $\mathrm{CD}^{+}$lymphocytes), in one of the 13 patients treated with $250 \mathrm{mg}$ twice daily (nausea), and in four of the five patients treated with $300 \mathrm{mg}$ twice daily (nausea and vomiting; elevation of ALT and AST; elevation of ALT, AST, and $\gamma$-GT; or reduction in the number of $\mathrm{CD} 4^{+}$lymphocytes and elevation of $\gamma$-GT). All DLTs were fully reversible after treatment discontinuation. The MTD for both once- and twice-daily dosing was thus $250 \mathrm{mg}$.

Another dose-escalation Phase I study was performed to determine the MTD and tolerability of nintedanib given on a twice-daily schedule in Japanese patients with advanced refractory solid tumors (Table 1). ${ }^{14}$ Twenty-one patients including 14 individuals with colorectal cancer, one with NSCLC, and one with small-cell lung cancer - were treated with nintedanib at doses of $150 \mathrm{mg}, 200 \mathrm{mg}$, or $250 \mathrm{mg}$ twice daily. None of the three patients treated with $150 \mathrm{mg}$ twice daily experienced a DLT, whereas DLTs occurred in three of the 12 patients who received $200 \mathrm{mg}$ twice daily and in three of the six patients who received $250 \mathrm{mg}$ twice daily. All of the DLTs consisted of elevation of liver enzymes (ALT, AST, or $\gamma$-GT increases of grade 3 or 4 ) in the absence of a relevant bilirubin increase, and they were fully

Table I Number of patients with DLTs (among evaluable patients) during the first course of nintedanib monotherapy in Phase I studies based in Germany ${ }^{13}$ and Japan ${ }^{14}$

\begin{tabular}{|c|c|c|c|}
\hline \multirow{2}{*}{$\begin{array}{l}\text { Nintedanib } \\
\text { dose }(\mathbf{m g})\end{array}$} & \multicolumn{2}{|l|}{ Germany $^{b}$} & \multirow{2}{*}{$\frac{\text { Japan }^{\text {b }}}{\text { Twice daily }}$} \\
\hline & Once daily & Twice daily & \\
\hline 50 & $0 / 2$ & $N / A$ & $N / A$ \\
\hline 100 & $0 / 1$ & $N / A$ & $N / A$ \\
\hline 150 & N/A & $0 / 6$ & $0 / 3$ \\
\hline $150+200$ & N/A & $0 / 6$ & $\mathrm{~N} / \mathrm{A}$ \\
\hline 200 & I/8 (hepatotoxicity) & I/6 (decline in CD4 ${ }^{+}$lymphocytes) & $3 / 12^{\text {a }}$ (hepatotoxicity) \\
\hline 250 & $1 / 6^{\mathrm{a}}$ (decline in $\mathrm{CD}^{+}$lymphocytes) & $\mathrm{I} / \mathrm{I} \mathrm{3}^{\mathrm{a}}$ (nausea) & 3/6 (hepatotoxicity) \\
\hline 300 & 2/5 (hepatotoxicity) & $\begin{array}{l}4 / 5 \text { (one with nausea and vomiting; one with decline } \\
\text { in CD4+ lymphocytes and hepatotoxicity; and two } \\
\text { with hepatotoxicity) }\end{array}$ & $N / A$ \\
\hline 450 & 2/3 (hepatotoxicity) & $N / A$ & $N / A$ \\
\hline
\end{tabular}

Notes: ${ }^{a}$ MTD. ${ }^{b}$ Data present as the number of patients with DLTs/number of patients eligible for evaluation of DLTs. Abbreviations: DLTs, dose-limiting toxicities; MTD, maximum tolerated dose; N/A, not applicable. 
reversible on cessation of treatment. Therefore, nintedanib was found to have an acceptable tolerability profile for Japanese patients with advanced solid tumors at doses up to $200 \mathrm{mg}$ twice daily, which was determined as the MTD. The MTD for Japanese subjects (200 mg twice daily) was thus lower than that for European patients (250 mg twice daily). Baseline and posttreatment levels of circulating CD117 (c-KIT)-positive bone-marrow-derived progenitor cell subsets as well as of plasma soluble VEGFR2 (sVEGFR2) were evaluated as potential biomarkers for the pharmacodynamics and dose-response relation of nintedanib. Levels of circulating $\mathrm{CD} 117^{+}$bone-marrow-derived progenitors and plasma sVEGFR2 decreased significantly during the treatment in all nintedanib dose cohorts, indicating that they might be associated with target inhibition by nintedanib.

\section{Ethnic variation in the MTD of nintedanib}

Liver toxicity featured prominently among DLTs of nintedanib monotherapy in both Japanese and European patients enrolled in Phase I trials, with such toxicity occurring at a greater frequency in the former patients than in the latter treated with the same doses (Table 1). ${ }^{13,14}$ These results led to a difference in the MTD of nintedanib monotherapy between European (250 mg twice daily) and Japanese (200 mg twice daily) patients. Pharmacokinetic differences may account for this difference in MTD. An analysis of nintedanib pharmacokinetics at steady state revealed that the mean maximal concentration $\left(C_{\max }\right)$ in plasma was $67.6 \mathrm{ng} / \mathrm{mL}$ and that the area under the curve was $423 \mathrm{ng}$.hour/mL in Japanese patients treated with $200 \mathrm{mg}$ twice daily, with these values being much higher than those for German patients also treated with $200 \mathrm{mg}$ twice daily $\left(C_{\max }\right.$ of $44.9 \mathrm{ng} / \mathrm{mL}$ and area under the curve of $303 \mathrm{ng} \cdot$ hour $/ \mathrm{mL}$ ). The difference in body size between Japanese and European patients may underlie these pharmacokinetic differences. Indeed, in the Phase I trial of nintedanib monotherapy in Japanese, three of the four patients with a body surface area (BSA) of $<1.5 \mathrm{~m}^{2}$ in the $200 \mathrm{mg}$ twice daily cohort developed DLTs (hepatic enzyme elevations of grade 3), whereas DLTs were not apparent in the eight patients with a BSA of $\geq 1.5 \mathrm{~m}^{2}$ treated with the same dose. Similar findings have been reported for patients treated with sunitinib or imatinib. Retrospective analysis of the relation between BSA and sunitinib toxicity in patients with metastatic renal cell cancer thus found that a low BSA was associated with a higher incidence of DLTs, which were retrospectively defined as any toxicity leading to a dose reduction or treatment discontinuation and included asthenia, stomatitis, proteinuria, and thrombotic microangiopathy. ${ }^{15}$ In addition, a Phase III trial comparing the efficacy and safety of imatinib with those of interferon- $\alpha$ plus low-dose cytarabine in patients with chronic myeloid leukemia positive for the Philadelphia chromosome found a weak inverse correlation between steady-state trough levels of imatinib and BSA. ${ }^{16}$ These previous studies provided valuable information for the prediction of nintedanib toxicity, with patients of small physical size, who required careful assessment of liver function during treatment, undergoing nintedanib therapy.

\section{Combination treatment with nintedanib \\ Nintedanib in combination with pemetrexed}

Given the encouraging results obtained in Phase I trials of nintedanib monotherapy, a Phase I study was conducted at two sites in the USA and Canada to assess the MTD, safety, and tolerability of nintedanib in combination with pemetrexed in patients with recurrent advanced NSCLC who had previously been treated with one platinum-based chemotherapeutic regimen (Table 2). ${ }^{17}$ Patients received a standard dose of pemetrexed $\left(500 \mathrm{mg} / \mathrm{m}^{2}\right)$ on day 1 followed by oral nintedanib twice daily on days $2-21$. Twenty-six patients were treated with nintedanib at doses of $100 \mathrm{mg}$, $150 \mathrm{mg}, 200 \mathrm{mg}$, or $250 \mathrm{mg}$ twice daily. DLTs occurred in one of the six patients treated with $100 \mathrm{mg}$ twice daily, in one of the six treated with $150 \mathrm{mg}$ twice daily, in three of

Table 2 Number of patients with DLTs (among evaluable patients) during the first course of nintedanib combination therapy in Phase I studies based in North America ${ }^{17}$ and Japan ${ }^{21}$

\begin{tabular}{|c|c|c|c|c|c|}
\hline \multirow{3}{*}{$\begin{array}{l}\begin{array}{l}\text { Nintedanib } \\
\text { dose (mg bid) }\end{array} \\
100\end{array}$} & \multirow{3}{*}{$\begin{array}{l}\text { North America }^{\mathrm{b}} \\
\text { With pemetrexed }\left(500 \mathrm{mg} / \mathrm{m}^{2}\right) \\
\mathrm{l} / 6\end{array}$} & \multicolumn{4}{|l|}{ Japan $^{\mathrm{b}}$} \\
\hline & & \multicolumn{2}{|c|}{ With docetaxel $\left(60 \mathrm{mg} / \mathrm{m}^{2}\right)$} & \multicolumn{2}{|c|}{ With docetaxel $\left(75 \mathrm{mg} / \mathrm{m}^{2}\right)$} \\
\hline & & $0 / 3$ & $\mathrm{~N} / \mathrm{A}$ & $\mathrm{N} / \mathrm{A}$ & $\mathrm{N} / \mathrm{A}$ \\
\hline 150 & $1 / 6$ & $2 / 6\left(B S A<1.5 m^{2}\right)$ & $0 / 3\left(B S A \geq 1.5 \mathrm{~m}^{2}\right)$ & $\mathrm{I} / 6\left(\mathrm{BSA}<\mathrm{I} .5 \mathrm{~m}^{2}\right)^{\mathrm{a}}$ & $2 / 6\left(B S A \geq 1.5 \mathrm{~m}^{2}\right)$ \\
\hline 200 & $3 / 12^{\mathrm{a}}$ & $3 / 3\left(B S A<1.5 m^{2}\right)$ & $2 / 6\left(B S A \geq 1.5 \mathrm{~m}^{2}\right)$ & $\mathrm{N} / \mathrm{A}$ & $2 / 6\left(B S A \geq 1.5 m^{2}\right)^{a}$ \\
\hline 250 & $2 / 2$ & $\mathrm{~N} / \mathrm{A}$ & $\mathrm{N} / \mathrm{A}$ & $\mathrm{N} / \mathrm{A}$ & $\mathrm{N} / \mathrm{A}$ \\
\hline
\end{tabular}

Notes: aMTD. ${ }^{b}$ Data present as the number of patients with DLTs/number of patients eligible for evaluation of DLTs. Abbreviations: DLTs, dose-limiting toxicities; MTD, maximum tolerated dose; BSA, body surface area; N/A, not applicable. 
the 12 treated with $200 \mathrm{mg}$ twice daily, and in both of the two treated with $250 \mathrm{mg}$ twice daily. Nintedanib at a dose of $200 \mathrm{mg}$ twice daily was thus found to be the recommended dose for continuous daily treatment in combination with standard-dose pemetrexed for patients with advanced or metastatic NSCLC.

A randomized Phase III trial (LUME-Lung 2) was performed to evaluate nintedanib (200 $\mathrm{mg}$ twice daily) plus pemetrexed $\left(500 \mathrm{mg} / \mathrm{m}^{2}\right)$ in comparison with pemetrexed alone in white patients with advanced nonsquamous NSCLC after the failure of first-line therapy. However, as a result of futility at a prespecified interim analysis based on investigator-assessed progression-free survival (PFS), the primary end point of the study, this trial was initially stopped. A subsequent analysis of the available intent-to-treat population based on independent review data showed a PFS benefit for patients treated with nintedanib plus pemetrexed compared with placebo plus pemetrexed (median PFS of 4.4 months versus 3.6 months; hazard ratio [HR] of 0.83 with a $95 \%$ confidence interval $[\mathrm{CI}]$ of $0.70-0.99 ; P=0.04$ ), but there was no difference in overall survival (OS) between the two arms. A higher incidence of elevated ALT $(23 \%$ versus $7 \%$ ) or AST (12\% versus $2 \%$ ) of grade $\geq 3$ as well as of diarrhea of grade $\geq 3$ (3\% versus $1 \%$ ) was apparent in patients treated with nintedanib and pemetrexed. ${ }^{18}$

\section{Nintedanib in combination with docetaxel}

A dose-escalation Phase I study assessing the safety and MTD of continuous daily treatment with nintedanib plus standard-dose docetaxel $\left(75 \mathrm{mg} / \mathrm{m}^{2}\right.$, every 3 weeks) and prednisone (5 mg twice daily) in European chemotherapynaïve patients with metastatic hormone-refractory prostate cancer found that $200 \mathrm{mg}$ twice daily was the recommended dose for nintedanib in this regimen. ${ }^{19}$

On the basis of the safety profile for this combination, a large Phase III trial (LUME-Lung 1) was conducted to evaluate docetaxel $\left(75 \mathrm{mg} / \mathrm{m}^{2}\right)$ plus nintedanib (200 $\mathrm{mg}$ twice daily) in comparison with docetaxel alone as second-line therapy for patients with advanced NSCLC. ${ }^{20}$ PFS, the primary end point of the trial, was significantly improved in the docetaxel-plusnintedanib group compared with the docetaxel-alone group (median of 3.4 months versus 2.7 months; HR of 0.79 with a $95 \%$ CI of $0.68-0.92 ; P=0.0019$ ), and OS was significantly improved for patients with adenocarcinoma tumor histology (median of 12.6 months versus 10.3 months; HR of 0.83 with a $95 \%$ CI of $0.70-0.99 ; P=0.0359$ ) but not for the total study population. Subgroup analysis of PFS according to demographic and baseline characteristics - including sex, age,
Eastern Cooperative Oncology Group performance status, and smoking status - was consistent with the primary analysis, favoring the docetaxel-plus-nintedanib group, whereas patients registered in the study within 9 months after initiation of first-line chemotherapy appeared to derive greater benefit from docetaxel plus nintedanib compared with those registered $\geq 9$ months after the onset of first-line treatment. These results indicated that nintedanib in combination with docetaxel is a potential option for patients who become refractory to first-line therapy within 9 months. Adverse events that were more common ( $\geq 10 \%$ difference for all grades) in the docetaxel-plus-nintedanib arm than in the docetaxelplus-placebo arm included diarrhea (all grades, $42.3 \%$ versus $21.8 \%$; grade $\geq 3,6.6 \%$ versus $2.6 \%$ ) as well as reversible increases in ALT (all grades, 28.5\% versus 8.4\%; grade $\geq 3$, $7.8 \%$ versus $0.9 \%$ ) and AST (all grades, $22.5 \%$ versus $6.6 \%$; grade $\geq 3,3.4 \%$ versus $0.5 \%$ ). Most of these adverse events were manageable with supportive treatment or dose reduction. The incidence of adverse events commonly associated with antiangiogenic agents, such as hypertension (all grades, 3.5\% versus $0.9 \%$ ), bleeding (all grades, 14.1\% versus $11.6 \%$ ), thrombotic events (all grades, 5.1\% versus 4.6\%), and gastrointestinal perforation (all grades, $0.5 \%$ versus $0.5 \%$ ), was similar in both groups. An adverse event leading to death possibly unrelated to disease progression was reported in $5.4 \%$ of patients in the docetaxel-plus-nintedanib group and in $3.8 \%$ of those in the docetaxel-plus-placebo group. This study is the first trial in the second-line setting to show a survival benefit for the combination of an antiangiogenic agent and chemotherapy in predefined NSCLC patients with adenocarcinoma tumor histology. On the basis of these results, nintedanib was approved by the European Union in November 2014 for the treatment of patients with advanced lung adenocarcinoma after the failure of first-line chemotherapy.

Another Phase III trial (LUME-Columbus) is currently in progress to investigate the efficacy and safety of combination treatment with nintedanib (200 mg twice daily) plus docetaxel $\left(75 \mathrm{mg} / \mathrm{m}^{2}\right)$ compared with placebo plus docetaxel $\left(75 \mathrm{mg} / \mathrm{m}^{2}\right)$ in individuals with advanced lung adenocarcinoma, including North American patients, after the failure of first-line chemotherapy (ClinicalTrials.gov identifier NCT02231164).

\section{Docetaxel plus nintedanib in Japanese patients}

A dose-escalation Phase I study was also conducted to define the MTD of nintedanib plus docetaxel in Japanese patients with advanced NSCLC following the failure of first-line 
platinum-based chemotherapy (Table 2). ${ }^{21}$ Eligible patients received $60 \mathrm{mg} / \mathrm{m}^{2}$ or $75 \mathrm{mg} / \mathrm{m}^{2}$ dose of docetaxel (day 1) plus $100 \mathrm{mg}, 150 \mathrm{mg}$, or $200 \mathrm{mg}$ doses of nintedanib twice daily (days 2-21) in 21-day cycles. No DLT was observed for the first (nintedanib at $100 \mathrm{mg}$ twice daily plus docetaxel at $60 \mathrm{mg} / \mathrm{m}^{2}$ ) and second (nintedanib at $150 \mathrm{mg}$ twice daily plus docetaxel at $60 \mathrm{mg} / \mathrm{m}^{2}$ ) cohorts; however, in the third cohort (nintedanib at $200 \mathrm{mg}$ twice daily plus docetaxel at $60 \mathrm{mg} / \mathrm{m}^{2}$ ), all three patients developed DLTs (elevation of liver enzymes), and these three patients had a BSA of $<1.5 \mathrm{~m}^{2}$. The protocol was then amended as a result of a recommendation by the external Efficacy and Safety Review Committee based on this early observation of a high incidence of DLTs in patients with a BSA of $<1.5 \mathrm{~m}^{2}$. Subsequent dose escalations were performed separately in two patient cohorts with a BSA of $<1.5 \mathrm{~m}^{2}$ or $\geq 1.5 \mathrm{~m}^{2}$. Of 12 patients with a BSA of $<1.5 \mathrm{~m}^{2}$ treated with nintedanib at $150 \mathrm{mg}$ twice daily plus docetaxel at either $60 \mathrm{mg} / \mathrm{m}^{2}(\mathrm{n}=6)$ or $75 \mathrm{mg} / \mathrm{m}^{2}(\mathrm{n}=6)$, three patients (two and one treated with docetaxel at $60 \mathrm{mg} / \mathrm{m}^{2}$ or $75 \mathrm{mg} / \mathrm{m}^{2}$, respectively) experienced DLTs (elevation of liver enzymes). Of 12 patients with a BSA of $\geq 1.5 \mathrm{~m}^{2}$ treated with nintedanib at $200 \mathrm{mg}$ twice daily plus docetaxel at either $60 \mathrm{mg} / \mathrm{m}^{2}(\mathrm{n}=6)$ or $75 \mathrm{mg} / \mathrm{m}^{2}(\mathrm{n}=6)$, two patients treated with each docetaxel dose experienced DLTs (elevation of liver enzymes). The MTD of nintedanib was thus determined to be $150 \mathrm{mg}$ and $200 \mathrm{mg}$ twice daily combined with docetaxel at $75 \mathrm{mg} / \mathrm{m}^{2}$ in patients with a BSA of $<1.5 \mathrm{~m}^{2}$ or $\geq 1.5 \mathrm{~m}^{2}$, respectively.

At the time that the opportunity for Japanese patients to join the global LUME-Columbus Phase III trial was considered, the lack of tolerability of nintedanib at a dose of $200 \mathrm{mg}$ twice daily in combination with docetaxel at $75 \mathrm{mg} / \mathrm{m}^{2}$ in patients with a BSA of $<1.5 \mathrm{~m}^{2}$ had not been demonstrated in the Japanese Phase I trial. Another Phase I study, an open-label safety run-in trial, is now planned to determine the appropriateness of nintedanib at a starting dose of $200 \mathrm{mg}$ twice daily plus docetaxel at $75 \mathrm{mg} / \mathrm{m}^{2}$ for Japanese patients with a BSA of $<1.5 \mathrm{~m}^{2}$ and locally advanced or metastatic adenocarcinoma after the failure of first-line platinum-based chemotherapy (ClinicalTrials.gov identifier NCT02300298).

\section{Conclusion}

A recent Phase III trial demonstrated that treatment with the combination of nintedanib and docetaxel resulted in a significant and clinically meaningful improvement in PFS and OS compared with docetaxel alone in predefined NSCLC patients with adenocarcinoma tumor histology. The combination had an acceptable and manageable safety profile, with no new or unexpected safety findings. There was a low incidence of class effects typically associated with antiangiogenic agents, such as hypertension, bleeding, perforation, and thromboembolism, which have been noted with other antiangiogenic agents in patients with NSCLC. Nintedanib in combination with docetaxel is thus a potential treatment option for patients with advanced NSCLC previously treated with one line of platinum-based therapy.

\section{Disclosure}

$\mathrm{IO}$ and $\mathrm{KN}$ have received honoraria from Nippon Boehringer Ingelheim. The authors report no other conflicts of interest in this work.

\section{References}

1. Schiller JH, Harrington D, Belani CP, et al; Eastern Cooperative Oncology Group. Comparison of four chemotherapy regimens for advanced non-small-cell lung cancer. $N$ Engl J Med. 2002;346(2):92-98.

2. Takeda M, Okamoto I, Sakai K, Kawakami H, Nishio K, Nakagawa K. Clinical outcome for EML4-ALK-positive patients with advanced non-small-cell lung cancer treated with first-line platinum-based chemotherapy. Ann Oncol. 2012;23(11):2931-2936.

3. Solomon BJ, Mok T, Kim DW, et al; PROFILE 1014 Investigators. First-line crizotinib versus chemotherapy in ALK-positive lung cancer. N Engl J Med. 2014;371(23):2167-2177.

4. Mitsudomi T, Morita S, Yatabe Y, et al; West Japan Oncology Group. Gefitinib versus cisplatin plus docetaxel in patients with non-smallcell lung cancer harbouring mutations of the epidermal growth factor receptor (WJTOG3405): an open label, randomised phase 3 trial. Lancet Oncol. 2010;11(2):121-128.

5. Maemondo M, Inoue A, Kobayashi K, et al; North-East Japan Study Group. Gefitinib or chemotherapy for non-small-cell lung cancer with mutated EGFR. N Engl J Med. 2010;362(25):2380-2388.

6. Folkman J. What is the evidence that tumors are angiogenesis dependent? J Natl Cancer Inst. 1990;82(1):4-6.

7. Seto T, Higashiyama M, Funai $\mathrm{H}$, et al. Prognostic value of expression of vascular endothelial growth factor and its flt- 1 and KDR receptors in stage I non-small-cell lung cancer. Lung Cancer. 2006;53(1):91-96.

8. Ferrara N, Gerber HP, LeCouter J. The biology of VEGF and its receptors. Nat Med. 2003;9(6):669-676.

9. Kim KJ, Li B, Winer J, et al. Inhibition of vascular endothelial growth factor-induced angiogenesis suppresses tumour growth in vivo. Nature. 1993;362(6423):841-844.

10. Reck M, von Pawel J, Zatloukal P, et al. Phase III trial of cisplatin plus gemcitabine with either placebo or bevacizumab as first-line therapy for nonsquamous non-small-cell lung cancer: AVAil. J Clin Oncol. 2009; 27(8):1227-1234.

11. Sandler A, Gray R, Perry MC, et al. Paclitaxel-carboplatin alone or with bevacizumab for non-small-cell lung cancer. N Engl J Med. 2006; 355(24):2542-2550

12. Hilberg F, Roth GJ, Krssak M, et al. BIBF 1120: triple angiokinase inhibitor with sustained receptor blockade and good antitumor efficacy. Cancer Res. 2008;68(12):4774-4782.

13. Mross K, Stefanic M, Gmehling D, et al. Phase I study of the angiogenesis inhibitor BIBF 1120 in patients with advanced solid tumors. Clin Cancer Res. 2010;16(1):311-319.

14. Okamoto I, Kaneda H, Satoh T, et al. Phase I safety, pharmacokinetic, and biomarker study of BIBF 1120, an oral triple tyrosine kinase inhibitor in patients with advanced solid tumors. Mol Cancer Ther. 2010; 9(10):2825-2833. 
15. Huillard O, Mir O, Peyromaure M, et al. Sarcopenia and body mass index predict sunitinib-induced early dose-limiting toxicities in renal cancer patients. Br J Cancer. 2013;108(5):1034-1041.

16. Larson RA, Druker BJ, Guilhot F, et al; IRIS (International Randomized Interferon vs STI571) Study Group. Imatinib pharmacokinetics and its correlation with response and safety in chronic-phase chronic myeloid leukemia: a subanalysis of the IRIS study. Blood. 2008;111(8): 4022-4028.

17. Ellis PM, Kaiser R, Zhao Y, Stopfer P, Gyorffy S, Hanna N. Phase I open-label study of continuous treatment with BIBF 1120, a triple angiokinase inhibitor, and pemetrexed in pretreated non-small cell lung cancer patients. Clin Cancer Res. 2010;16(10):2881-2889.

18. Hanna N, Kaiser R, Sullivan R, et al. Lume-lung 2: a multicenter, randomized, double-blind, phase III study of nintedanib plus pemetrexed versus placebo plus pemetrexed in patients with advanced nonsquamous non-small cell lung cancer (NSCLC) after failure of first-line chemotherapy. J Clin Oncol. 2013;31:sul;abstr8034.
19. Bousquet G, Alexandre J, Le Tourneau C, et al. Phase I study of BIBF 1120 with docetaxel and prednisone in metastatic chemo-naive hormone-refractory prostate cancer patients. Br J Cancer. 2011;105(11): 1640-1645.

20. Reck M, Kaiser R, Mellemgaard A, et al; LUME-Lung 1 Study Group. Docetaxel plus nintedanib versus docetaxel plus placebo in patients with previously treated non-small-cell lung cancer (LUME-Lung 1): a phase 3, double-blind, randomised controlled trial. Lancet Oncol. 2014;15(2): $143-155$.

21. Okamoto I, Miyazaki M, Takeda M, et al. Tolerability of nintedanib (BIBF 1120) in combination with docetaxel: a phase 1 study in Japanese patients with previously treated non-small-cell lung cancer. $J$ Thorac Oncol. 2015;10(2):346-352.
Therapeutics and Clinical Risk Management

\section{Publish your work in this journal}

Therapeutics and Clinical Risk Management is an international, peerreviewed journal of clinical therapeutics and risk management, focusing on concise rapid reporting of clinical studies in all therapeutic areas, outcomes, safety, and programs for the effective, safe, and sustained use of medicines. This journal is indexed on PubMed Central, CAS,

\section{Dovepress}

EMBase, Scopus and the Elsevier Bibliographic databases. The manuscript management system is completely online and includes a very quick and fair peer-review system, which is all easy to use. Visit http://www.dovepress.com/testimonials.php to read real quotes from published authors. 